\title{
Note
}

\section{New size record for Snapping Turtle (Chelydra serpentina) in southern Quebec, Canada}

\author{
Patrick Galois ${ }^{1}$, *, Ève-Lyne Grenier ${ }^{2}$, and Martin Ouellet $^{2}$ \\ ${ }^{1}$ Amphibia-Nature, 2932 rue Saint-Émile, Montréal, Quebec H1L 5N5 Canada \\ ${ }^{2}$ Amphibia-Nature, 23 rue Turenne, Saint-Charles-Borromée, Quebec J6E 7P4 Canada \\ ${ }^{*}$ Corresponding author: pgalois@amphibia-nature.org
}

Galois, P., Ė.-L. Grenier, and M. Ouellet. 2018. New size record for Snapping Turtle (Chelydra serpentina) in southern Quebec, Canada. Canadian Field-Naturalist 132(4): 378-381. https://doi.org/10.22621/cfn.v132i4.2021

\begin{abstract}
We report a new size record for a Snapping Turtle (Chelydra serpentina) in Quebec, Canada. We captured an adult male in good general condition in the Rivière du Sud in the southern Montérégie region. Its straight midline carapace length was $43.2 \mathrm{~cm}$ (maximum carapace length $45.1 \mathrm{~cm}$ ), and it weighed $19.8 \mathrm{~kg}$. This record contributes to our understanding of the maximum size of this species at the northeastern part of its range. More intensive effort will be necessary to document the Snapping Turtle population structure in Quebec to allow for sound comparisons with other populations, as well as a better understanding of the effects of elevation, latitude, and local habitat on Snapping Turtle growth and size.
\end{abstract}

Key words: Snapping Turtle; Chelydra serpentina; size record; Rivière du Sud; northeastern range; Quebec; Canada

\section{Résumé}

Nous rapportons un nouveau record de taille pour une tortue serpentine (Chelydra serpentina) au Québec, Canada. Nous avons capturé un mâle adulte en bonne condition générale dans la rivière du Sud dans le sud de la Montérégie. La longueur standard de la carapace était de $43,2 \mathrm{~cm}$ (longueur maximale de la carapace $45,1 \mathrm{~cm}$ ) et il pesait $19,8 \mathrm{~kg}$. Ce record contribue à une meilleure connaissance sur les tailles maximales de l'espèce dans le nord-est de son aire de répartition. Des efforts plus importants seront nécessaires pour documenter la structure de population de la tortue serpentine au Québec afin de permettre des comparaisons fiables avec d'autres populations, ainsi qu'une meilleure compréhension des effets de l'altitude, de la latitude et de l'habitat local sur la croissance et la taille de la tortue serpentine.

Mots-clés: tortue serpentine; Chelydra serpentina; record de taille; rivière du Sud; nord-est de l'aire de répartition; Québec; Canada

Finding the largest individuals of a turtle species in a given region requires perseverance and good data collection methods. Since 1992, we have been conducting research and managing an observation network to gather information related to herpetofauna distribution, reproduction, road mortality, and abnormal colouration and morphology among other topics. Observations from the public often consist of female turtles seen crossing a road or digging a nest in a garden during nesting season or turtles captured accidentally during sport fishing (Galois and Ouellet 2007a,b; Amphibia-Nature Observation Network unpubl. data). Reported size is usually a visual approximation, especially when the subject is an impressive Snapping Turtle (Chelydra serpentina). Despite the limited number of this species, occasional captures made during our biodiversity projects provide reliable and precise data. Here, we report the largest Snapping Turtle documented in Quebec, Canada.

The observation was made during a biodiversity survey in the Rivière du Sud, a tributary of the Rivière Richelieu, in Quebec's southern Montérégie region. After capturing the Snapping Turtle from a boat using a dip net, we examined it for general condition, measured

it, and documented the observation using digital photography.

We used a forestry caliper (Dendrotik, Quebec, Canada) to measure to the nearest millimetre the straight midline carapace length $\left(\mathrm{CL}_{\text {mid }}\right)$, maximum carapace length $\left(\mathrm{CL}_{\max }\right)$, maximum shell width $(\mathrm{SW})$, straight midline plastron length $\left(\mathrm{PL}_{\text {mid }}\right)$, posterior lobe length of the plastron (middle scales suture of the plastron to the posterior end), precloacal length (posterior end of the plastron to the centre of the cloaca), and posterior end of the plastron to the tail extremity. To weigh the turtle, we used a 22.0-kg spring scale (Matzuo America, Illinois, USA) with $0.2-\mathrm{kg}$ gradation. We released the turtle at the point of capture immediately after the measurements were made.

We searched the literature to obtain published information on Snapping Turtle size in North America. We also checked our own database for information we collected in the field and obtained through our observation network (https://www.amphibia-nature.org).

We captured the adult male Snapping Turtle on 3 July 2016 in the Rivière du Sud, Quebec $\left(45^{\circ} 05^{\prime} \mathrm{N}, 73^{\circ} 13^{\prime} \mathrm{W}\right.$; datum WGS84). At the capture location, the river was characterized by slow moving water and shallow river-

A contribution towards the cost of this publication has been provided by the Thomas Manning Memorial Fund of the Ottawa Field-Naturalists' Club. 
ine marsh, with the navigable open section limited to a narrow channel (Figure 1). The turtle was lying in shallow water on a muddy substrate. As we approached at reduced speed, the turtle started to move slowly beside the boat, allowing capture.

The turtle's dimensions were: $\mathrm{CL}_{\text {mid }} 43.2 \mathrm{~cm}$ (Figure 2), $\mathrm{CL}_{\max } 45.1 \mathrm{~cm}, \mathrm{SW} 36.0 \mathrm{~cm}$, and $\mathrm{PL}_{\text {mid }} 30.2 \mathrm{~cm}$. The distance between the posterior end of the plastron and the tail extremity was $42.4 \mathrm{~cm}$. Total weight was $19.8 \mathrm{~kg}$. With a morphological ratio of precloacal length $(17.8 \mathrm{~cm})$ to plastron posterior lobe length $(12.8 \mathrm{~cm})$ of 1.39 , the turtle was determined to be male (Ernst and Lovich 2009; Dustman 2013). The turtle was in good general condition with no apparent injuries. Five leeches (Placobdella parasitica) were present on the carapace.

To our knowledge, the carapace length of this Snapping Turtle is the longest measured and reported in Quebec. In June 1939, a large turtle was captured on a road near Van Bruyssel, a hamlet in the Mauricie region, and brought to the Jardin zoologique de Québec (Bernard 1948). Reported measurements were: CL 18 inches $(45.7 \mathrm{~cm})$ and weight 30 pounds $(13.6 \mathrm{~kg})$. Unfortunately, it was not specified whether the carapace measurement was taken as a straight line or along the carapace curvature, and no picture was provided. Moreover, the weight of this turtle was abnormally low in relation to the carapace length based on data from other studies (Lagler and Applegate 1943; Hammer 1969; Johnston et al. 2012); therefore, the measurements are considered questionable. Two other well documented large male Snapping Turtles found in Quebec each had a $\mathrm{CL}_{\max }$ of $43.0 \mathrm{~cm}$ (Desroches 2007), $2.1 \mathrm{~cm}$ shorter than our record. One of these was found dead in 2003 in the same area as our observation in the Rivière du Sud.

Large male Snapping Turtles have been reported in the literature from various locations in North America. Snapping Turtle males grow larger than females, and female size tends to increase with increasing latitude and elevation (Moll and Iverson 2008). In Minnesota, at $47^{\circ} 37^{\prime} \mathrm{N}$, further north than our observation area, a male Snapping Turtle had a CL of $49.4 \mathrm{~cm}$ (not specified whether straight midline or maximum; Gerholdt and Oldfield 1987). In comparison with our observation, this conforms to the latitude trend of larger individuals in the north. However, in Ontario's Algonquin Park, a latitude $\left(45^{\circ} 35^{\prime} \mathrm{N}\right)$ close to that of our area, the largest male captured had a $\mathrm{CL}_{\text {mid }}$ of $39.5 \mathrm{~cm}$ (Obbard 1977), i.e., smaller than our record. In Massachusetts (Middlesex County centroid $42^{\circ} 28^{\prime} \mathrm{N}$ ), a male turtle's unspecified CL was $50.7 \mathrm{~cm}$ (Hunter et al. 1992), and, in Nebraska $\left(41^{\circ} 44^{\prime} \mathrm{N}\right)$, the largest individual captured in Island Lake had an unspecified CL of $46.4 \mathrm{~cm}$ (Iver-

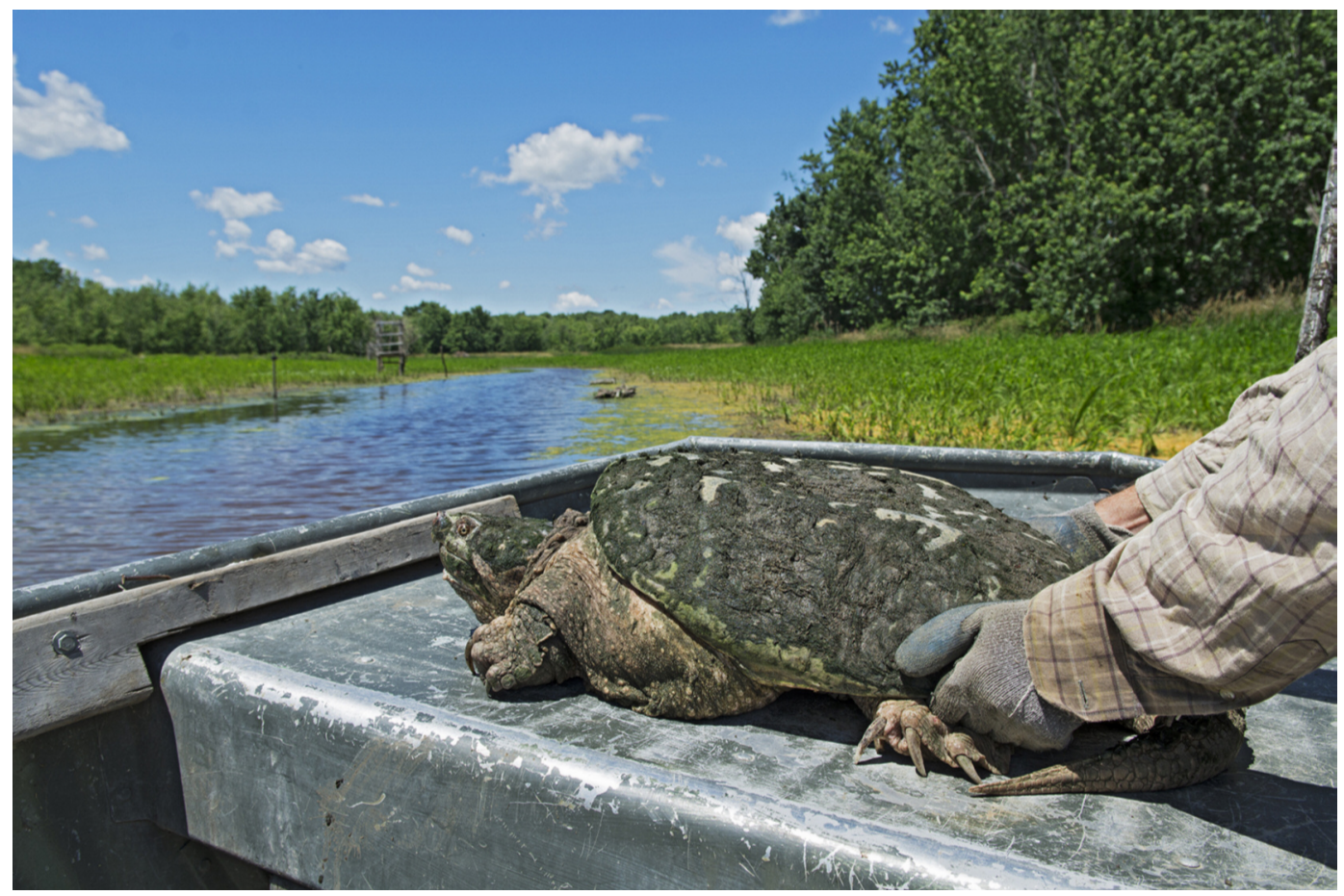

Figure 1. Adult Snapping Turtle (Chelydra serpentina) captured in the Rivière du Sud in southern Quebec, Canada. Photo: È.-L. Grenier. 


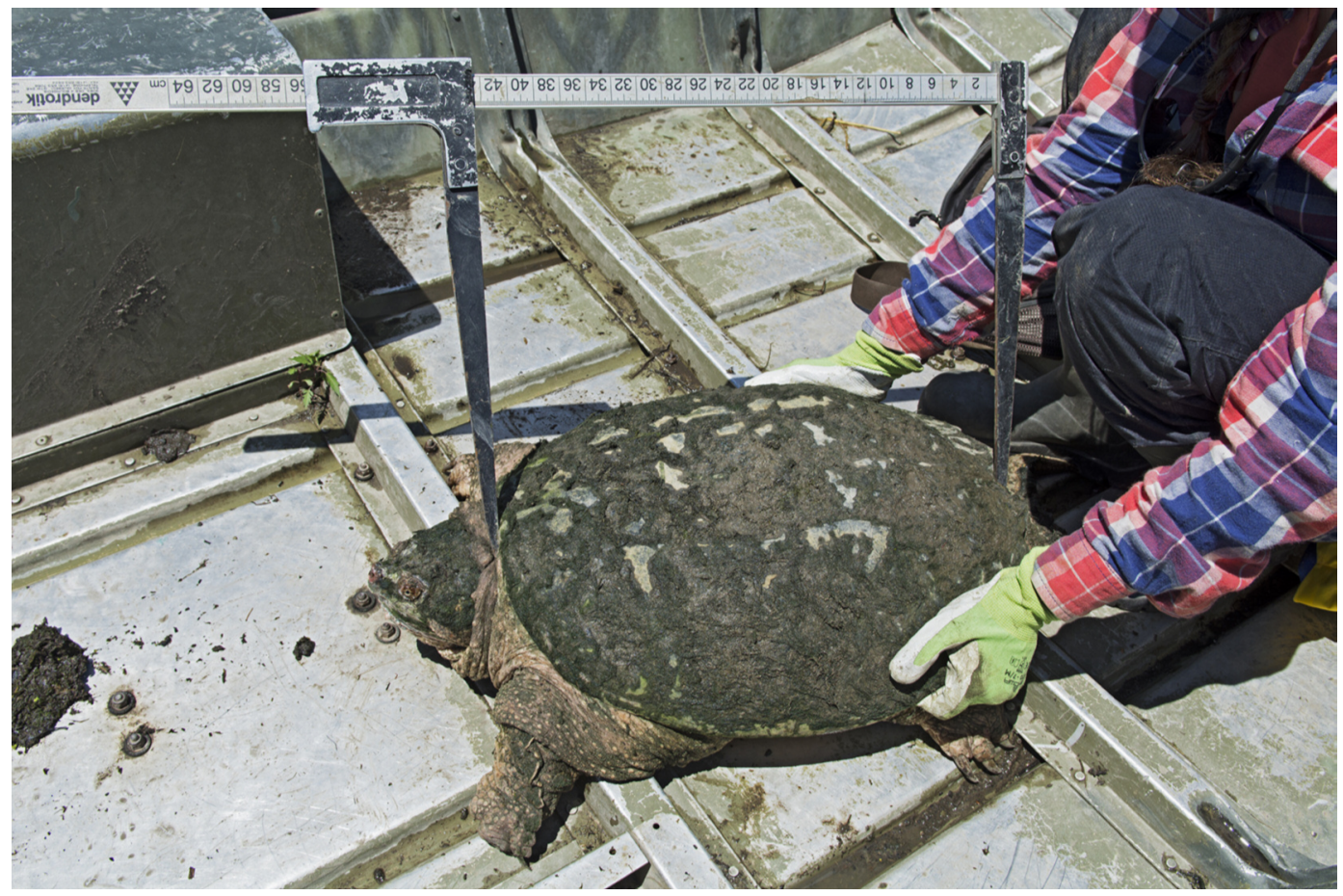

FIGURE 2. The observed Snapping Turtle (Chelydra serpentina) was a male with a straight midline carapace length of $43.2 \mathrm{~cm}$ and a maximum carapace length of $45.1 \mathrm{~cm}$. Photo: P. Galois.

son et al. 1997). The largest males in Florida populations in the Santa Fe River $\left(29^{\circ} 52^{\prime} \mathrm{N}\right)$ and in Wekiwa Springs State Park $\left(28^{\circ} 43^{\prime} \mathrm{N}\right)$ had $\mathrm{CL}_{\max }$ of $45.0 \mathrm{~cm}$ (Johnston et al. 2012) and $44.8 \mathrm{~cm}$ (Walde et al. 2016), respectively. These measurements are only a few millimetres smaller than our record, but they are also smaller than some $\mathrm{CL}_{\max }$ reported in other northern latitudes (Gerholdt and Oldfield 1987; Hunter et al. 1992).

Thus, these size records for male Snapping Turtles do not support the suggested relation between latitude and maximum size. The same discrepancies can also be found for females. A large female $\left(\mathrm{CL}_{\text {mid }} 37.3 \mathrm{~cm}\right.$, $\mathrm{CL}_{\max } 39.9 \mathrm{~cm}$ ) was found dead in Parc National des Îles-de-Boucherville $\left(45^{\circ} 36^{\prime} \mathrm{N}\right)$ near Montréal, Quebec (Desroches 2007). In 2015, we captured a female with $\mathrm{CL}_{\text {mid }} 37.0 \mathrm{~cm}$ in Parc-nature du Bois-de-l'Île-Bizard $\left(45^{\circ} 30^{\prime} \mathrm{N}\right)$ near Montréal, Quebec (P.G. and M.O. unpubl. data). A large female with $\mathrm{CL}_{\text {mid }} 35.8 \mathrm{~cm}$ was captured in Algonquin Park (Obbard 1977), and a female with unspecified CL $38.4 \mathrm{~cm}$ was captured in South Dakota $\left(43^{\circ} 09 ' \mathrm{~N}\right.$; Hammer 1969). The largest female in a Florida population had a $\mathrm{CL}_{\text {mid }}$ of $38.0 \mathrm{~cm}$ (Johnston et al. 2012), close or even larger than female $\mathrm{CL}_{\text {mid }}$ reported in some northern populations. Thus, the relation between latitude and both male and female Snapping Turtle size needs further investigation.
Although size records are of interest, they remain anecdotal until ample data are collected to verify whether these large individuals are exceptional or relatively common in their populations. More intensive effort is necessary to document Snapping Turtle sizes and population structure in Quebec, at the northeastern limit of the species range, to allow more useful comparisons with other northern and southern populations. These studies would allow for a better understanding of the effects of elevation, latitude, and local habitat on Snapping Turtle growth and size. They would also provide data relevant to investigations of the effect of climate change on Snapping Turtle population structure over time.

A climate warming trend at northern latitudes could favour an extension of the species range toward the northeast by providing a long enough period for successful egg incubation. We already know that Snapping Turtle reproduction occurs as far north as $48^{\circ} 19^{\prime} \mathrm{N}$ in Abitibi, western Quebec (Lapointe 2018). In Canada, Snapping Turtle observations range northward to $51^{\circ} \mathrm{N}$ in western Ontario and $52^{\circ} \mathrm{N}$ in Manitoba (COSEWIC 2008). Therefore, additional information on Snapping Turtle distribution and population structure at northern latitudes is particularly important to allow for the documentation of potential changes over time in response to climate change. Our turtle observation network is an 
effective tool to obtain information from remote locations. Details, including date and location, and photos can be submitted online (https://www.amphibia-nature. org) or sent to info@amphibia-nature.org. With or without measurements, this information might help in identifying sites where more intensive surveys could eventually be undertaken to improve knowledge of Snapping Turtle populations at the northern limit of their range.

\section{Author Contributions}

Field work, Writing - Review \& Editing: P.G., È.-L.G, and M.O.

\section{Acknowledgements}

We thank Daniel and Nicolas Forget for sharing their knowledge on wildlife and history of the Richelieu River area and their precious help in the field. Our biodiversity projects are carried out in compliance with the Canadian Council for Animal Care guidelines. We also thank anonymous reviewers whose comments helped to improve this manuscript.

\section{Literature Cited}

Bernard, R. 1948. Note faunique. Page 126 in Les Carnets de la Société Zoologique de Québec 1940-1941-1942. Second Edition. Société Zoologique de Québec, Quebec, Canada.

COSEWIC (Committee on the Status of Endangered Wildlife in Canada). 2008. COSEWIC assessment and status report on the Snapping Turtle Chelydra serpentina in Canada. COSEWIC, Ottawa, Ontario, Canada. Accessed 19 April 2019. https://tinyurl.com/y7de5vef.

Desroches, J.-F. 2007. Les plus grosses tortues serpentines (Chelydra s. serpentina) du Québec. Naturaliste Canadien 131(1): 41-45.

Dustman, E. 2013. Sex identification in the common snapping turtle (Chelydra serpentina): a new technique and evaluation of previous methods. Herpetological Review 44: 235238.

Ernst, C.H., and J.E. Lovich. 2009. Turtles of the United States and Canada. Johns Hopkins University Press, Baltimore, Maryland, USA.

Galois, P., and M. Ouellet. 2007a. Health and disease in Canadian reptile populations. Pages 131-168 in Ecology, Conservation, and Status of Reptiles in Canada. Edited by C.N.L. Seburn and C.A. Bishop. Herpetological Conserva- tion, volume 2. Society for the Study of Amphibians and Reptiles, Salt Lake City, Utah, USA.

Galois, P., and M. Ouellet. 2007b. Traumatic injuries in eastern spiny softshell turtles (Apalone spinifera) due to recreational activities in the northern Lake Champlain basin. Chelonian Conservation and Biology 6: 288-293. https:// doi.org/10.2744/1071-8443(2007)6[288:TIIESS]2.0.CO;2

Gerholdt, J.E., and B. Oldfield. 1987. Chelydra serpentina serpentina (Common Snapping Turtle). Size. Herpetological Review 18: 73.

Hammer, D.A. 1969. Parameters of a marsh snapping turtle population Lacreek Refuge, South Dakota. Journal of Wildlife Management 33: 995-1005. https://doi.org/10.2307/ 3799337

Hunter, M.L., J. Albright, and J. Arbuckle. 1992. The amphibians and reptiles of Maine. Bulletin 838. Maine Agricultural Experiment Station, Orono, Maine, USA.

Iverson, J.B., H. Higgins, A. Sirulnik, and C. Griffiths. 1997. Local and geographic variation in the reproductive biology of the snapping turtle (Chelydra serpentina). Herpetologica 53: 96-117.

Johnston, G.R., E. Suarez, J.C. Mitchell, G.A. Shemitz, P.L. Butt, and M. Kaunert. 2012. Population ecology of the snapping turtle (Chelydra serpentina osceola) in a northern Florida river. Bulletin of the Florida Museum of Natural History 51: 243-256.

Lagler, K.F., and V.C. Applegate. 1943. Relationship between the length and the weight in the snapping turtle Chelydra serpentina Linnaeus. American Naturalist 77: 476-478. https://doi.org/10.1086/281150

Lapointe, J. 2018. Chelydra serpentina (Snapping Turtle). Nesting range expansion. Herpetological Review 49: 316317.

Moll, D., and J.B. Iverson. 2008. Geographic variation in lifehistory traits. Pages 181-192 in Biology of the Snapping Turtle (Chelydra serpentina). Edited by A.C. Steyermarck, M.S. Finkler, and R.J. Brooks. Johns Hopkins University Press, Baltimore, Maryland, USA.

Obbard, M.E. 1977. Population ecology of the common snapping turtle, Chelydra serpentina, in north-central Ontario. Ph.D. thesis, University of Guelph, Guelph, Ontario, Canada.

Walde, A.D., E.C. Munscher, and A.M. Walde. 2016. Record size Chelydra serpentina (snapping turtle) from Florida's freshwater springs. Southeastern Naturalist 15: 16-22. https://doi.org/10.1656/058.015.0216

Received 29 November 2017

Accepted 8 January 2019 